\title{
PROSES ADAPTASI MAHASISWA BINUS UNIVERSITY ASAL DAERAH
}

\author{
Tukina \\ Marketing Communication Department, Faculty of Economic and Communication, BINUS University \\ Jln. K.H. Syahdan No. 9, Palmerah, Jakarta Barat 11480 \\ tukino_uki06@yahoo.com
}

\begin{abstract}
Research on the adaptation process of students from other regions aim to answer fundamental things related to the adaptation process of students from other regions who are studying at Binus University. Appropriate adaptation process can help create conducive environment to achieve good quality of learning (good quality of education). With good adaptability, students are expected to graduate well too. Becoming excellent graduates are the dream of every student, parents and university as well as community and country. Research of adaptation process of students from other regions who are studying at Binus University was conducted with descriptive qualitative methodology, the data obtained through in-depth interviews in the field and then were exposed to inductive analysis through the stages planned. To support the study, data collection is done in the following way: observation, survey, search and find key informants, and conducted in-depth interviews. Once the data is collected and analyzed then the next step is to generate data on the final results report. Students who come from other regions view that the process of adaptation is important and should be done. What is important and should be done in an adaptation process includes several things, such as the distance between students' new area of domicile to campus, social culture in students' place of origin to the students' new area of domicile, and the situation of environmental conditions (society) of students' place of origin to students' new domicile as well as individual specific views (attitudes and behaviors ). Students from other regions adapt in a variety of ways, ranging from respecting new area of domicile custom, getting involved in students' activities in campus and to comply with regulations. Adaptation also needs to be done to the entire academic community, including with other related environment. From the results of the study also showed that students who come from other regions view adaptation process is associated with learning outcomes at the university.
\end{abstract}

Keywords: Process, Adaptation, behaviours, culture, social changes

\begin{abstract}
ABSTRAK
Penelitian mengenai proses adaptasi mahasiswa yang berasal dari daerah ini bertujuan untuk menjawab hal mendasar berkaitan dengan proses adaptasi mahasiswa dari daerah yang sedang belajar di Binus University. Proses adaptasi yang tepat dapat membantu menciptakaan lingkungan yang kodusif agar tercapai kualitas perkuliahan (kualitas Pendidikan) yang baik. Dengan kemampuan beradaptasi yang baik, mahasiswa diharapkan dapat lulus dengan baik pula. Lulusan yang baik merupakan harapan setiap mahasiswa, orang tua dan universitas serta tentunya masyarakat dan negara. Penelitian proses adaptasi mahasiswa asal daerah yang sedang belajar di Binus University ini dilakukan dengan metodologi kualitatif deskriptif, data didapat melalui wawancara mendalam di lapangan kemudian dipaparkan secara analisis induktif melalui tahap-tahap yang sudah direncanakan. Untuk mendukung penelitian tersebut, pengumpulan datadilakukan dengan cara sebagai berikut: observasi, survey, mencari dan menemukan key informan, dan wawancara yang dilakukan secara mendalam. Setelah data terkumpul dan dianalisis maka langkah berikutnya adalah menyusun data tersebut dalam laporan hasil akhir. Mahasiswa yang berasal dari daerah memandang bahwa proses adaptasi merupakan hal yang penting dan harus dilakukan. Tingkatan penting dan harus dilakukannya sebuah proses adaptasi meliputi beberapa hal, seperti masalah jauh dekat domisili mahasiswa yang berasal dari daerah dengan Kampus, sosial budaya daerah asal dan baru, dan situasi kondisi lingkungan (masyarakat) asal dan lingkungan baru serta pandangan individu (sikap dan perilaku) tertentu. Mahasiswa yang berasal dari daerah melakukan adaptasi dengan berbagai cara, mulai dari berperilaku sopan, ikut terlibat dalam kegiatankemahasiswaan sampai mematuhi peraturan kampus. Adaptasi juga perlu dilakukan terhadap seluruh civitas akademika termasuk dengan lingkungan lainnya yang terkait. Dari hasil penelitian menunjukan pula bahwa mahasiswa yang berasal dari daerah memandang proses adaptasi sangat berkaitan dengan hasil belajar di universitas.
\end{abstract}

Kata kunci: proses, adaptasi, sikap perilaku, kebudayaan, perubahan sosial 


\section{PENDAHULUAN}

\section{Latar Belakang}

Pendidikan tinggi atau dikenal luas dengan universitas memiliki peran yang sangat penting dalam membentuk manusia yang unggul dan berkualitas. Universitas merupakan tempat untuk belajar bagi mahasiswa. Peran universitas untuk menjadikan manusia yang utuh, memiliki pengetahuan, cerdas, tangguh dan berkarakter merupakan tugas yang tidak mudah. Peran itulah yang dilakukan Binus University dengan berusaha menjawab tantangan globalisasi ke depan dalam rangka mewujudkan keinginan menjadikan mahasiswa dapat menggunakan segenap ilmu pengetahuan dan keahlian dalam kehidupan yang nyata. Peran universitas untuk menjadikan mahasiswa berhasil dalam studinya merupakan tantangan dan sekaligus jawaban di era globalisasi dewasa ini. Mewujudkan keberhasilan studi di universitas merupakan langkah mendasar dan penting. Binus University adalah sebuah universitas di Ibukota negara dengan jumlah mahasiswa mencapai ribuan dan memiliki beragam latar belakang etnis. Kehidupan mahasiswa Binus University sangat beragam, dalam hal penampilan, budaya yang dibawa, sikap dan perilaku, serta kebiasaan. Beragamnya latar belakang etnis mahasiswa Binus University merupakan sesuatu yang menarik untuk diteliti. Oleh karena itu, penelitian ini berupaya mencari jawaban bagaimana proses adaptasi mahasiswa yang berasal dari daerah dalam belajar di Binus University.

\section{Tujuan dan Manfaat Penelitian}

Permasalahan Penelitian yang ingin dijawab dalam penelitian ini adalah bagaimana proses adaptasi mahasiswa Binus University yang berasal dari daerah. Proses adaptasi mahasiswa asal daerah merupakan hal penting untuk menunjang perkuliahan di universitas. Oleh karena itu, penelitian ini memiliki tujuan sebagai berikut:

\section{Tujuan Penelitian}

Untuk mengetahui latar belakang daerah asal mahasiswa, proses adaptasi dan keberhasilan studi mahasiswa di Binus University

\section{Manfaat Penelitian}

Untuk menjelaskan proses adaptasi mahasiswa yang berasal dari daerah dan keberhasilan mahasiswa dalam belajar di Binus University

\section{Keutamaan Penelitian}

Peran penting universitas sebagai tolak ukur bagi kemajuan negara di era globalisasi ini merupakan hal yang sangat mendasar. Binus University berdiri kokoh dipusat ibu kota negara memiliki keunikan tersendiri. Sebagai universitas yang berada di pusat ibu kota negara, Binus University memiliki ribuan mahasiswa dengan latar belakang yang beragam. Keberagaman daerah asal mahasiswa, ada yang berasal dari ibukota Jakarta --Betawi--, dan ada yang berasal dari berbagai daerah lainnya di Indonesia bahkan ada juga yang berasal dari manca negara. Daerah asal mahasiswa yang beragam tersebut menarik untuk dikaji dalam sebuah penelitian tentang bagaimana proses adaptasi mahasiswa. 


\section{Kajian Pustaka}

\section{Istilah Proses}

Istilah proses merujuk http://id.wikipedia.org/wiki/Proses adalah berkaitan dengan urutan pelaksanaan (kejadian yang terjadi secara alami atau dirancang berdasar waktu, ruang dan keahlian atau hal lainnya, yang menghasilkan suatu hasil. Suatu proses dikenali oleh perubahan yang diciptakan terhadap sifat dari sesuatu atau objek di bawah pengaruhnya. Menurut Proji Dewanti (2012) Proses adaptasi berkaitan dengan psikologi seseorang. Oleh karena itu penelitian ini yang akan mengkaji orang atau mahasiswa yang berasal dari daerah yang belajar di Binus University menjadi sangat penting. Penelitian ini yang akan difokuskan pada proses adaptasi mahasiswa Binus University yang berasal dari daerah merupakan penelitian yang akan dilaksanakan untuk mengetahui pentingnya proses adaptasi dalam kaitan dengan tingkat keberhasilan kuliah di universitas.

\section{Teori Komunikasi Antar Budaya}

Komunikasi Antar Budaya (Intercultural communication) terjadi bila sebuah pesan (message) yang harus dipahami dihasilkan oleh anggota dari budaya tertentu untuk konsumsi anggota dari budaya yang lain (Samovar \& Porter, 1994). Komunikasi antar budaya berkaitan dengan proses interaksi antar pribadi dan komunikasi antar pribadi yang dilakukan oleh beberapa orang yang memiliki latar belakang kebudayaan yang berbeda. Komunikasi antar budaya (Intercultural communication) merupakan bagian dari proses komunikasi.

Komunikasi antara satu orang dengan orang yang lain dengan latar belakang budaya yang berbeda melahirkan komunikasi antar budaya. Dalam komunikasi antar budaya terdapat banyak hambatan (communication barrier). Hambatan komunikasi dalam komunikasi antar budaya (intercultural communication) mempunyai bentuk seperti sebuah gunung es yang terbenam di dalam air. Hambatan komunikasi antar budaya antara lain berkaitan dengan sikap dan perilaku seseorang.

\section{Teori Perubahan Sosial dan Globalisasi}

Perubahan sosial adalah perubahan tatanan sosial suatu masyarakat. Perubahan sosial berkaitan dengan perubahan yang penting atas struktur sosial dan budaya dalam suatu rentang waktu tertentu. Perubahan struktur sosial berkaitan erat dengan pola sikap perilaku seseorang dan Interaksinya dalam kehidupan sosial. Perubahan menyangkut pula perubahan norma, nilai dan fenomena kultural. Perubahan sosial merupakan suatu proses yang memiliki perubahan struktur dan fungsi suatu sistem sosial. Perubahan tersebut terjadi karena masuknya ide-ide pembaruan yang diadopsi oleh para anggota sistem sosial yang bersangkutan. Perubahan menyangkut kegiatan atau proses yang membuat sesuatu atau seseorang berbeda dengan keadaan sebelumnya (mengalami perubahan) dan itu menyebabkan perubahan pola sikap perilaku individu. Menurut Selo Soemardjan, perubahan-perubahan sosial adalah segala perubahan pada lembaga-lembaga kemasyarakatan dalam suatu masyarakat yang mempengaruhi sistem sosialnya, termasuk didalamnya nilai-nilai, sikap-sikap dan pola-pola perilaku (manusia) diantara kelompok-kelompok dalam masyarakat.

\section{Teori Adaptasi}

Istilah adaptasi diambil untuk menjelaskan dan menekankan serta menggambarkan ketika manusia menghadapi situasi dan kondisi yang berubah dan berbeda. Adaptasi dilakukan ketika terjadi suatu ketimpangan dalam suatu situasi dan kondisi (keadaan/sistem). Ketimpangan terjadi akibat interaksi manusia dengan lingkungan, tuntutan lingkungan yang berlebih atau kebutuhan yang tidak sesuai dengan situasi lingkungan. Adaptasi merupakan suatu proses respon/tanggapan atas kehadiran 
stimulus secara berkelanjutan. Adaptasi lebih banyak berkaitan dengan suasana batin dan jiwa untuk dapat menyesuaikan situasi kondisi dan keadaan yang ada.

\section{METODE}

Penelitian ini dilakukan di Binus University, Jakarta. Metode penelitian yang digunakan bersifat kualitatif deskriptif yakni memaparkan sekaligus melakukan interpretasi terhadap gejala yang diteliti (terkait situasi dan atau peristiwa), dan tidak untuk menguji hipotesa.

\section{Metode Pengumpulan Data}

Sumber data yang digunakan dalam penelitian ini: data primer; diperoleh melalui wawancara mendalam dengan menggunakan pedoman wawancara (terstruktur) yang sudah dipersiapkan terlebih dahulu. Wawancara terstruktur tersebut dilakukan terhadap beberapa mahasiswa yang dipandang sebagai tokoh kunci/utama (key informan). Data sekunder; diperoleh melalui Jurnal-jurnal penelitian, buku-buku, makalah, suratkabar, dan pencarian informasi melalui internet (browser).

\section{Metode Analisis Data}

Data yang terkumpul akan dianalisis secara induktif berdasarkan tujuan penelitian. Data akan dikumpulkan sampai dianggap cukup oleh peneliti. Menurut W. Lowrence Neuman (2011) Peran peneliti sangat sentral dalam penelitian kualitatif. Untuk mempermudah penelitian maka dilakukan observasi, penyusunan dan pengujian instrument wawancara, wawancara mendalam, penyusunan dan penyelesaian pelaporan hasil penelitian dan diakhiri dengan tahap diseminasi dan sosialisasi hasil penelitian.

\section{HASIL DAN PEMBAHASAN}

\section{Deskripsi Asal Daerah Mahasiswa}

Mahasiswa Binus University berasal dari berbagai daerah. Binus sendiri merupakan kampus di pusat kota Jakarta, yang modern, ramai dan padat. Jakarta merupakan kota yang kompleks dan menurut Ahmadi Mustopa (2011) kehidupan di Jakarta itu seperti benang kusut dan perlu diuraikan/dicarikan solusi. Penelitian ini difokuskan pada adaptasi mahasiswa yang berasal dari daerah. Wawancara mendalam dilakukan kurang lebih selama tiga bulan dan diperkuat dengan pemantauan di lapangan dan observasi (pengamatan). Wawancara secara mendalam dilakukan kepada mahasiswa yang berasal dari berbagai daerah. Karena penelitian adaptasi mahasiswa yang berasal dari daerah di Binus University merupakan penelitian kualitatif, maka peranan peneliti sendiri dalam menggali dan mengolah secara mendalam menjadi sangat penting dan menentukan.

Mahasiswa Binus University dapat digambarkan secara umum; Pertama, untuk mahasiswa yang berasal tidak terlalu jauh dari Jakarta (baca dekat dengan Jakarta), seperti Bogor, Tanggerang, Cikarang dan Sukabumi rata-rata menyatakan wilayahnya tidak begitu berbeda jauh dari Jakarta, apalagi banyak diantara mahasiswa yang pulang pergi (PP/mahasiswa 'penglaju'), namun ada yang terasa perbedaannya secara umum yaitu hidup di Jakarta lebih ramai, sibuk dan individualis terutama bila dibanding dengan asal mahasiswa tersebut. 
Kedua, mahasiswa yang berasal daerah yang tidak terlalu jauh tetapi juga tidak dekat. Kelompok mahasiswa yang kedua ini dicirikan sulit untuk pulang pergi ketika kuliah bahkan sebagian dapat dikatakan tidak mungkin di 'penglaju' (Pulang Pergi/PP). Kelompok mahasiswa kedua ini berasal dari daerah seperti Cirebon, Pekalongan, Semarang, Malang, Palembang, Jambi dan daerahdaerah sekitarnya. Kelompok mahasiswa kedua ini memandang adaptasi diperlukan secara relative karena memandang daerah asalnya berbeda dengan situasi dan kondisi kampus di Pusat Kota termasuk masyarakatnya.

Kelompok ketiga, yaitu mahasiswa yang berasal jauh dari Jakarta. Mahasiswa yang berasal jauh dari Jakarta memandang kehidupan baru/masyarakat baru sangat berbeda dengan daerah asalnya. Disinilah adaptasi perlu dilakukan lebih menyeluruh dan kompleks, bukan hanya dalam kehidupan bermasyarakat, situasi dan kondisi yang serba berbeda dan juga tentunya dengan kampus yang terletak di pusat kota besar di Jakarta dengan penduduk yang sangat padat, permasalahan yang rumit, serta kemacetan merupakan tantangan tersendiri bahkan bisa jadi menjadi problem/masalah tersendiri.

\section{Mahasiswa Asal Daerah dan Proses Adaptasi}

Mahasiswa Binus University berasal dari berbagai daerah di Indonesia. Asal daerah yang berbeda-beda memerlukan proses beradaptasi yang berbeda-beda pula. Untuk mahasiswa yang berasal dari daerah yang berada di daerah sekitar Jakarta tidak mengalami perubahan lingkungan yang mencolok. Hal ini berbeda dengan mahasiswa yang berasal dari daerah yang jauh dari Jakarta, mahasiswa asal daerah tersebut akan menemui lingkungan baru yang mungkin berbeda dengan lingkungan sebelumnya. Oleh karena itu, kemampuan adaptasi menjadi hal yang menarik, semakin diperlukan dan semakin penting bahkan mungkin menjadi sesuatu yang sangat penting.

Proses adaptasi mahasiswa asal daerah di Jakarta berbeda dan unik. Adaptasi menjadi berbeda karena asal daerah dengan latar belakang yang berbeda sehingga mengakibatkan proses adaptasi juga berbeda dan Adaptasi menjadi khas karena setiap pribadi mahasiswa adalah pribadi yang berbeda. Disitulah terletak kekhasan dari sosok mahasiswa asal daerah. Dalam proses tersebut, ada mahasiswa yang memandang adaptasi merupakan sesuatu yang diperlukan dan penting dalam belajar di Universitas. Ada pula mahasiswa asal daerah yang berpandangan lain yaitu adaptasi diperlukan tetapi bukan hal yang utama dan ada pula yang beranggapan bahwa adaptasi merupakan kunci utama belajar di universitas. Yang menarik dari berbagai pandangan tersebut, semakin jauh daerah asal mahasiswa asal daerah dari Jakarta maka mahasiswa tersebut menganggap perlu untuk beradaptasi dan bagi mereka adaptasi merupakan sesuatu yang penting.

Beberapa mahasiswa beralasan proses adaptasi diperlukan tapi bukan menjadi prioritas, mereka lebih memrioritasnya nilai perkuliahan yang bagus. Pandangan yang demikian biasa terjadi pada mahasiswa yang berasal dari daerah yang daerah mereka berasal berjarak dekat dengan Jakarta atau memiliki kemiripan situasi sosial dengan Jakarta, seperti Batam, Pekanbaru, dan Surabaya. Pandangan bahwa proses adaptasi diperlukan tetapi bukan menjadi prioritas banyak dimiliki mahasiswa yang berasal dari daerah sekitar Jakarta. Kebanyakan mereka memerlukan proses adaptasi terbatas pada hal-hal tertent seperti adaptasi dalam hal cara belajar yang berbeda. Mahasiswa yang berasal dari daerah tetapi hidup dan tinggal di Jakarta atau yang sebagian besar waktu mereka dihabiskan di Jakarta atau di kota-kota besar di Indonesia serupa Jakarta, menganggap proses adaptasi diperlukan dalam hal-hal tertentu saja. Mahasiswa dengan kriteria seperti ini banyak dijumpai di universitas dan hal ini terjadi karena berbagai sebab, seperti antara lain mengikuti orang tua mahasiswa yang berpindah-pindah domisili. 


\section{Pentingnya Adaptasi Bagi Mahasiswa}

Secara umum mahasiswa yang berasal dari daerah menganggap proses adaptasi merupakan hal penting, karena: (1) Mahasiswa dapat lebih nyaman dalam berinteraksi dengan lingkungan baru dan dalam belajar. (2) Mahasiswa yang berasal dari daerah dapat belajar banyak dari lingkungan. (3) Adaptasi dapat menciptakan efek dan suasana hati tertentu. (4) Penyesuaian dengan lingkungan dan masyarakat baru merupakan hal yang penting sehingga mahasiswa dapat diterima dengan lingkungan baru dengan baik dan dapat berinteraksi dengan situasi dan kondisi masyarakat sekitar. (5) Mahasiswa yang berasal dari daerah dapat lebih berkonsentrasi dalam belajar. (6) Membantu dan membentuk kedewasaan dan sikap mental mahasiswa yang baik. (7) Mahasiswa dapat bertahan dengan kondisi psikologi dan fisik yang prima.

\section{Bagaimana Mahasiswa Beradaptasi}

\section{Lingkungan Mahasiswa}

Mahasiswa yang berasal dari daerah yang menuntut ilmu di Binus University harus melalui proses adaptasi dengan berinteraksi dengan lingkungan sekitar kehidupan mereka yang meliputi: pertama, Lingkungan masyarakat di sekitar daerah domisili mahasiswa. Mahasiswa yang kuliah di Binus University banyak yang berasal dari luar Jakarta. Mahasiswa yang berasal dari daerah tersebut merasakan perbedaan yang ada dalam lingkungan kampus. Untuk mengatasi perbedaan tersebut maka diperlukan adaptasi, agar mahasiswa yang berasal dari daerah dapat menyatu dengan lingkungan baru yang nantinya akan menjadi bagian kehidupan mereka. Proses beradaptasi pada awalnya akan terlihat sulit, oleh karena itu harus adanya kesiapan mental yang kuat agar adaptasi dapat berjalan dengan baik. Lingkungan masyarakat termasuk kampus merupakan salah satu faktor pendukung untuk mensukseskan perkuliahan diri yang berhubungan secara langsung dengan keberhasilan studi di kampus.

Kedua, civitas akademika secara idiomatis berarti kelompok/komunitas/warga akademik. civitas akademika berkaitan dengan warga akademik, Di dalam civitas akademika terdapat dosen, mahasiswa dan karyawan yang memiliki peran sentral. Sebutan warga akademik sejajar dengan warga kampus (universitas), walaupun kedua istilah tersebut tidak sama tetapi ada kemiripan. Perbedaan mendasar civitas akademika dan warga kampus terutama terletak istilah warga kampus dapat berarti semua yang ada di kampus dan bisa jadi tidak ada hubungannya secara langsung dengan akademik, misalnya pedagang dan tamu. Warga akademik tidak dapat dipisahkan dengan lingkungan kampus. Dalam lingkungan civitas akademika ini mahasiswa yang berasal dari daerah akan berinteraksi dengan (1) Pimpinan universitas dan jajarannya. Mahasiswa memandang perlu melakukan adaptasi dengan pimpinan universitas dan jajarannya. Adaptasi dilakukan dengan cara : (a) Mengenal dengan baik, mengetahui tugas dan fungsi pimpinan kampus dan jajarannya. (b) Bersikap ramah (beretika dan sopan santun), tidak kaku dan sering berinteraksi. (c) Aktif di organisasi kemahasiswaan, seperti Himpunan Mahasiswa Jurusan (HMJ/HIMA) dan Unit Kegiatan Mahasiswa (UKM). (d) Melakukan komunikasi dengan baik termasuk melalui sosial media, seperti facebook, twiter dan yahoo dengan unsur pimpinan. (e) Memahami dan mentaati tata aturan (aturan akademik) yang berlaku. (f) Memperhatikan sifat, sikap dan perilaku pimpinan dan mencoba menyesuaikan. (2) Staff Pengajar (dosen). Mahasiswa memandang adaptasi dengan dosen perlu dilakukan dengan cara: (a) Berinteraksi dengan dengan dosen baik pada waktu kegiatan akademik maupun non akademik. (b) Menciptakan kedekatan dengan dosen dengan cara seperti mengerjakan tugas, dan assistensi project serta mengikuti dengan baik proses perkuliahan didalam kelas. (c) Mengenal karakter dosen, setelah itu berusaha menyesuaikan dengan karakter dosen tersebut. (d) Duduk dibarisan depan, mencatat, bertanya (dengan sopan) dan berusaha dikenal oleh dosen. (f) Mencatat kontak dosen dan menanyakan bila tidak mengerti melalui media komunikasi termasuk melalui media sosial (g) mengikuti peraturan dan tata cara perkulihan yang telah ditetapkan. (3) Mahasiswa (sesama teman mahasiswa). Adaptasi dengan 
sesama mahasiswa perlu dilakukan, dengan cara : (a) Berkenalan dan menjalin pertemanan secara baik dan luas. (b) Berbagi pendapat dan bertukar pikiran sesama teman. (c) Memahami lingkungan baru, keadan baru dan temen baru. (d) Membentuk kelompok belajar dan komunitas temen belajar baru. (e) saling mengerti dan memahami diantara mahasiswa. (f) Memperbanyak temen dan berinteraksi serta membangun relasi (hubungan) yang luas. (g) Menjadi pribadi yang enak diajak bicara dan tidak sombong serta menciptakan lingkungan sosial yang baik. (g) Berbaur dan cepat akrab dengan teman mahasiswa (bergaul). (4) Karyawan (Pegawai/Staff). Di dalam kampus peranan karyawan dalam mendukung perkuliahan sangat penting, mahasiswa dapat beradaptasi dengan cara : (a) Berbicara dan bersikap sopan-santun dan tidak membikin masalah. (b) Menghormati, mengetahui, dan dapat mengerti (memahami) fungsi dan tugas karyawan. (c) Sopan, murah senyum, mengenal karakter dan mengakrapi karyawan. (d) Melakukan interaksi dengan baik serta mampu menyesuaikan diri (e) Mengikuti aturan dan prosedur yang ada. (5) Lingkungan Perpustakaan Kampus. Perpustakaan merupakan "jantung universitas", dalam berinteraksi di dalam perpustakaan, mahasiswa dapat beradaptasi dengan cara: (a) Mahasiswa perlu menjaga dengan baik semua yang ada di perpustakaan. Buku-buku di Perpustakaan milik bersama dan berbeda dengan buku milik diri pribadi oleh karena perlu dijaga secara bersama-sama untuk kepentingan bersama. (b) Sistem perpustakaan di Binus University berbeda dan selalu berkembang (update). Mahasiswa perlu untuk menyesuaikan dengan hal-hal yang baru tersebut. (c) Mahasiswa dapat menggunakan Perpustakaan dan fasilitas pendukungnya dengan nyaman dan sesuai aturan yang berlaku. (6) Sarana dan Prasarana Penunjang/Fasilitas Kegiatan Kampus. Dalam mengunakan sarana dan prasarana penunjang kegiatan, mahasiswa perlu melakukan adaptasi. Pengunaan fasilitas tersebut perlu mematuhi aturan yang ada. Aturan perlu dilakukan agar sarana dan prasarana yang ada dapat dimanfaatkan semaksimal mungkin untuk kepentingan banyak mahasiswa. Penjagaan fasilitas yang ada perlu dilakukan secara bersamasama. Penggunaan fasilitas sarana dan prasarana jika tidak disertai dengan adaptasi yang baik akan mengakibatkan kerusakan.

\section{Masalah dalam Proses Adaptasi Mahasiswa}

Dalam beradaptasi dengan lingkungan sekitar, baik di dalam lingkungan kampus atau di luar lingkungan kampus, mahasiswa sering menghadapi masalah. Masalah-masalah tersebut adalah sebagai berikut: (1) Masalah Pribadi dan dan kehidupan Kampus. Mahasiswa harus dapat memisahkan antara kehidupan pribadi dan kehidupan dalam kampus, tetapi jika dalam kehidupan pribadi seseorang telah ditanamkan etika yang baik maka perilaku di dalam kampus akan mencerminkan perilaku yang baik pula sesuai dengan apa yang mereka dapat dari lingkungan pribadi mereka. Jika telah memutuskan menjadi mahasiwa, maka harus bisa berpikir profesional ketika menghadapi masalah sebesar apapun, serta tidak boleh emosional dalam mengatasinya terutama pada saat proses perkuliahan berlangsung. (2) Mahasiswa dalam Studi/Belajar. Kemampuan adaptasi sangat dibutuhkan dalam proses perkuliahan karena hal tersebut dapat mempengaruhi cara berpikir seseorang, dan pada akhirnya nanti akan mempengaruhi nilai seseorang. Banyak problem yang dialami oleh mahasiswa bila adaptasi yang ia lakukan tidak berjalan dengan lancar, hal tersebut akan berkaitan dengan mental dan psikis seorang mahasiswa. Mahasiswa akan merasa terdiskriminasi dan menjadi malas untuk belajar sehingga berpengaruh terhadap hasil nilai didalam kelas. Pergaulan juga akan menimbulkan masalah jika terjebak dalam pergaulan yang salah sehingga berpengaruh dalam hasil studinya. (3) Materi Perkuliahan. Kemampuan adaptasi terhadap materi perkuliahan meliputi hubungan dosen dan mahasiswa. Jika dosen dan mahasiswa dapat saling berinteraksi dengan baik maka materi yang disampaikan pun tidak akan terhambat. Mahasiswa akan merasa nyaman jika dapat berinteraksi dengan dosen yang dapat mengajar dengan baik dan dapat mengerti apa yang diinginkan mahasiswa. Mahasiwa harus sebaliknya, mahasiswa harus menghormati dan menghargai apa yang telah disampaikan oleh dosen. Sehingga dalam proses perkuliahan akan lebih terasa nyaman. (4) Problem terhadap Dosen/Staff pengajar. Adaptasi terhadap dosen dan staff pengajar memang diperlukan, karena hal tersebut dapat mendukung suasana yang harmonis di dalam kelas, dengan adanya suasana yang harmonis makanya ketika belajar mahasiswa akan merasa nyaman. Ada beberapa masalah yang 
sering terjadi sehingga mahasiswa tidak dapat beradaptasi dengan dosen yaitu ketika dosen tersebut menutup diri, bersikap tidak ramah, ataupun dosen tersebut terlihat jelas dalam memberikan materi, hal ini akan mengakibatkan mahasiswa tidak dapat mengerti apa yang disampaikan oleh dosen tersebut. (5) Problem terhadap Unsur Pimpinan dan Jurusan. Untuk mengetahui unsur pimpinan dan jurusan, mahasiswa harus mengikuti peraturan-peraturan yang telah diterapkan, mengikuti kegiatankegiatan yang dilaksanakan oleh Binus University, melalui organisasi yang ada didalam kampus, mengikuti program-program khusus yang dapat membantu untuk mengenal lingkungan kampus. Problem yang sering dihadapi dalam hal ini adalah ada pelanggaran ketentuan, tata terib dan peraturan kampus. (6) Sarana dan Prasarana Kampus. Beradaptasi dengan sarana dan prasarana kampus merupakan hal yang penting karena segala aktivitas yang dilakukan dalam perkuliahan pasti akan menggunakan sarana-prasarana yang disediakan oleh kampus. Jika mahasiswa tidak dapat beradaptasi maka akan tidak mengetahui informasi-informasi yang terjadi dalam lingkungan perkuliahan dan tidak dapat menikmati fasilitas yang disediakan. Setiap mahasiswa seharusnya wajib untuk mengetahui segala sarana-prasarana apa yang ada didalam lingkungan kampus. (7) Keberhasilan Studi/belajar Mahasiswa. Keberhasilan belajar mahasiswa sangat bergantung pada lingkungan keluarga, kampus, masyarakat dan juga pertemenan. Bila mahasiswa tersebut merasa nyaman dengan apa yang ada di lingkungan sekitar maka mahasiswa akan merasa nyaman ketika belajar dan hal ini akan membawa keberhasilan bagi dirinya.

\section{Kemampuan Adaptasi dan Indeks Prestasi (IPk) Mahasiswa}

Kemampuan adaptasi mahasiswa dan prestasi mahasiswa dalam perkuliahan saling berhubungan dan mempengaruhi satu dengan yang lainnya. Kemampuan adaptasi yang baik akan membuat prestasi yang baik dalam perkuliahan, sementara kemampuan adaptasi yang kurang akan membuat prestasi yang kurang pula dalam perkuliahan. Beragam tingkat kemampuan adaptasi yang mempengaruhi tingkat prestasi perkuliahan tersebut terbagi dalam empat katagori seperti di bawah ini.

Pertama, mahasiswa memiliki kemampuan adaptasi yang buruk akan memiliki prestasi perkuliahan yang buruk. Adaptasi mahasiswa yang buruk akan berpengaruh pada perkuliahan. Dengan adaptasi yang buruk, mahasiswa tidak merasa nyaman dengan diri sendiri dan lingkungan belajar. Mahasiswa merasakan tidak bisa menyatu dan apapun yang dilakukan berakhir dengan hasil yang tidak baik sehingga motivasi dalam dirinya menurun. Apabila hal ini berlanjut, maka akan membuat kemampuan beradaptasinya semakin buruk. Adaptasi yang buruk mempengaruhi pencapaian Indeks Prestasi Kumulatif (IPK) mahasiswa, karena adaptasi yang buruk mempengaruhi proses belajar, proses pemikiran serta mengurangi motivasi dan niat untuk belajar dengan baik.

Kedua, mahasiswa memiliki kemampuan adaptasi sedang. Kemampuan adaptasi sedang menunjukkan seseorang tersebut masih ragu-ragu terhadap lingkungan sekitarnya, walaupun begitu, semangat untuk bisa menyesuaikan diri masih ada tapi hal itu masih antara mau atau tidak mau. Hal ini terjadi karena proses adaptasi yang salah sejak awal berinteraksi. Adaptasi dilakukan dengan separuh hati atau hanya sekedar saja dan tidak mau mencoba untuk lebih baik lagi.

Ketiga, mahasiswa memiliki Kemampuan Adaptasi yang Baik. Mahasiswa yang memiliki kemampuan adaptasi dengan baik adalah mahasiswa yang benar-benar mempunyai niat untuk mencari ilmu bukan hanya kuliah sebagai rutinitas semata. Ketika seseorang melakukan adaptasi dengan baik maka akan terbangun keselarasan dalam lingkungan perkuliahan sehingga mampu beradaptasi dengan segala hal yang berkaitan denga perkuliahan. Proses belajar menjadi lebih baik karena adaptasi yang baik dengan dosen-dosen pengajar. Mahasiswa yang memiliki kemampuan adaptasi yang baik selalu mempunyai motivasi belajar yang baik. Mahasiswa akan mengerti dengan baik tentang segala hal yang telah diajarkan kepadanya sehingga mendapatkan nilai yang baik pula. 
Keempat, mahasiswa memilik Kemampuan Adaptasi yang Sangat Baik. Mahasiswa yang memiliki kemampuan adaptasi yang sangat baik maka akan ikut berperan aktif dalam segala hal, baik dilingkungan kampus maupun dalam proses perkuliahan dan organisasi. Mahasiswa seperti ini akan aktif dalam segala kegiatan yang dilaksanakan dan mencoba mengikuti kegiatan tersebut sesuai bidang yang digelutinya. Hal ini dapat menambah tingkat adaptasi dan jangakauan pemikiran yang lebih luas lagi sehingga mahasiswa ini mempunyai kecepatan dalam berinteraksi dengan siapa saja dan mampu membaur dengan siapa saja

\section{SIMPULAN}

Mahasiswa di Jakarta yang berasal dari daerah memerlukan proses adaptasi untuk dapat menyesuaikan diri dengan lingkungan kehidupan yang baru yang meliputi masyarakat, teman, kampus dan civitas akademika. Semakin jauh daerah asal seorang mahasiswa dari Jakarta maka mahasiswa tersebut semakin merasakan pentingnya beradaptasi, sedangkan semakin dekat daerah asal seorang mahasiswa dari Jakarta mahasiswa tersebut merasa memerlukan adaptasi namun bukan sesuatu yang penting. Dalam pandangan mahasiswa secara umum, adaptasi merupakan hal yang penting dan harus dilakukan. Adaptasi merupakan hal yang penting dan harus dilakukan karena hal tersebut dipandang sangat berkaitan dengan proses belajar di universitas. Proses adaptasi mahasiswa yang berasal dari daerah menunjukkan tingkatan penting dan wajib dilakukan. Tingkatan penting dan wajib ini dipengaruhi hal-hal yang sangat kompleks, beberapa hal yang mempengaruhi adalah asal daerah mahasiswa, termasuk jauh atau dekatnya dari Jakarta, dimana kampus/universitas tersebut berada, sosial budaya asal dan baru, serta masyarakat/lingkungan lama dan baru.

Mahasiswa yang berasal dari daerah perlu beradaptasi dengan lingkungan masyarakat termasuk lingkungan masyarakat baru di sekitar kampus. Proses beradaptasi melibatkan banyak hal dengan cara yang beragam. Proses beradaptasi meliputi hal yang sangat luas dan kompleks melibatkan banyak hal dalam lingkungan dan masyarakat yang baru, lingkungan kampus dan civitas akademika, sarana dan fasilitas kampus dan lain sebagainya. Keberhasilan proses beradaptasi tersebut, dapat menentukan berhasil tidaknya seseorang mahasiswa yang berasal dari daerah dalam belajar di universitas. Dalam proses tersebut, semakin dapat beradaptasi maka keberhasilan semakin terbuka lebar dan semakin tidak dapat beradaptasi maka akan semakin banyak kesulitan dalam belajar di universitas. Dengan demikian, cepat atau lambat mahasiswa yang berasal dari daerah dalam beradaptasi berkaitan erat dengan cepat atau lambat keberhasilan kuliah di universitas. Mahasiswa yang semakin cepat beradaptasi akan semakin berhasil dalam studi di universitas dan sebaliknya mahasiswa yang lambat beradaptasi akan terlambat pula proses belajar di universitas.

\section{Rekomendasi}

Penelitian ini dapat menjadi dasar penentuan dan pembuatan kebijakan di universitas agar memperhatikan proses mahasiswa beradaptasi. Hal ini penting karena proses adaptasi berkaitan erat dengan keberhasilan studi mahasiswa di universitas.

Bagi Jurusan perlu membuat program pengenalan dan pembimbingan kepada mahasiswa dengan memperhatikan karakteristik mahasiswa yang berbeda-beda, terutama yang berasal dari daerah. Program tersebut penting untuk mengarahkan proses adaptasi mahasiswa terutama yang berasal dari daerah agar dapat berjalan dengan baik. Dan perlu pula dilakukan pengawasan yang lebih intens agar mahasiswa dapat melakukan proses adaptasi dengan baik.

Perlu penelitian lebih lanjut berkaitan dengan problem adaptasi di lapangan untuk menjawab berbagai hambatan terkait dengan proses adaptasi mahasiswa yang berasal dari daerah. 


\section{DAFTAR PUSTAKA}

Dewanti, P (15 November 2012). Proses Adaptasi Menurut Psykologi. Diakses dari http://id.shvoong.com/social-sciences/psychology/2264514-proses-adaptasi-menurutpsikologi/\#ixzz2FIpR0533

Istilah proses (18 November 2012). Diakses dari http://id.wikipedia.org/wiki/Proses

Mustopa, A. (edt). (2011). Mengurai Benang Khusut Metropolitan. Jakarta : RM Books.

Neuman, W. L., (2011). Social Research Methods., Qualitative and Quantitative Approach. International Edition. PERASON. PEARSON Education Inc, Publishing as Allyn and Bacon.

Panduan Penelitian Hibah Binus. (2012)

Samovar, L., Porter, R., (1994). Intercultural communication: A reader. Wadsworth Pub. Co.

Sztomka, P.(2010). Sosiologi Perubahan Sosial. Jakarta: Prenada. 